\title{
Can Science Tame Politics: The Collapse of the New GMO Regime in the EU
}

On 2 March 2010 the European Commission authorised the cultivation of a BASF's genetically modified potato "Amflora" throughout the European Union. This came after a tortuous process commenced in 1996 and so far it is the only authorisation of a GMO for cultivation in EU since the current regulation was established. ${ }^{1}$ On 3 March 2010, President Barroso announced that the Commission intends to propose amendments to the current regulation to allow the Member States to prohibit the cultivation of GMO authorised for cultivation in the EU and it did so on June 13, 2010. This is one of the very few cases where decision-making power is effectively devolved back from Union to state level; it is even more impressive that this is happening on the initiative of the Commission and despite the obvious negative consequences for the internal market. ${ }^{2}$ In the meantime BASF botched the 2011 growing season for Amflora in Sweden and in 2012 announced that it withdraws its GM crops from the EU. This article follows the saga of the first and only cultivation authorisation under the current GMO regime and purports to find the reasons why it entailed its immediate collapse.

\section{The Controversy}

The historic context of the GMO regulation in EU and the controversies with the US in WTO are well-known. ${ }^{3}$ It is widely accepted that the BSA (mad cow) disease and several other prominent food scares in Europe throughout the 90s lead to salience and polarised opinions on what elsewhere appears as "technical" issue and to the widespread aversion to GMOs in Europe. Actually the scepticism to GMOs predates these scares; Morris and Spillane in their historic account of biotech regulation in EU note that "if compliance with rules is a key indicator of legitimacy, by the mid 1990's the EU's GMO regulatory framework was beginning to loose its legitimacy." ${ }^{4}$ Many member states invoked the safeguard clauses in the regulation then in force to ban

\footnotetext{
${ }^{1}$ This is the only authorisation for cultivation issued so far under the current regime. There is another GMO which can be grown - the maize MON810, but it was authorised in the 90s under the old regime. There are several other GMOs which were authorised under the current regime but for use only and they must be grown elsewhere.

2 Yet even though the announcement of the prospective regime change was prompted by the authorisation of the Amflora, it was by no means caused by it; the prospect for amendments was conceived as early as 2008 (see below).

${ }^{3}$ For detailed and comprehensive accounts of the issues in the context of international law and the transatlantic relations see Alberto Alemanno, Trade in Food: Regulatory and Judicial Approaches in the EU and the WTO (Cameron May 2007) and also Mark A. Pollack and Gregory C. Shaffer, When cooperation fails: the international law and politics of genetically modified foods (Gregory C. Shaffer ed, Oxford University Press 2009).

${ }^{4}$ For a detailed history of the biotech regulation in EU see Shane H. Morris and Charles Spillane, 'EU GM crop Regulation: A Road to Resolution or a Regulatory Roundabout?' (2010) 1 European Journal of Risk Regulation 359.
} 
GMOs on their territory; by 1998 twelve of them have declared that they would not support any new authorisations. In the face of that, the Commission ceased authorisation procedures and thus the notorious de facto moratorium began. It lasted till 2004 and in the meantime a brand new regime for GMO regulation in EU was elaborated and established.

The new regime was difficult to devise not only because of the substantive controversy between pro and anti camps but also because the EU context imposes several imperatives which further confounded the controversy. The first is the need for a pan-European regime for GMOs demanded by the principles of free movement. Apparently on this salient topic the Member States could not trust each other to recourse to mutual recognition which provides solution to many other comparable issues. The second imperative of course was the need for compliance with the free trade rules of the WTO, which allow to the EU institutions only limited space for choice of regime. Finally, the constitutional arrangements of the EU requires cooperation between states and institutions for any decision to be taken at all.

The regime that resulted from the interplay of all these factors is the most stringent in the world and was supposed to be the final settlement of the heated controversy as the votes of both the GMO proponents and opponents were necessary for its adoption. It makes the authorisations heavily dependent on scientific assessment thus "placing a greater burden and reliance upon advisory expertise." ${ }^{5}$ According to a seasoned observer, "To manage the conflict, the Commission invoked 'sciencebased regulation', implicitly equating science with advice from EU-level expert bodies." 6 This intent was clear:

The independence of their technical and/or scientific assessments is, in fact, their real raison d'être. The main advantage of using the agencies is that their decisions are based on purely technical evaluations of very high quality and are not influenced by political or contingent considerations. ${ }^{7}$

On a more cynical account, the regime sought to take the controversy away from the political institutions of the Member States and allow them to avoid responsibility for the subsequent decisions. ${ }^{8}$ While there may be nothing wrong with such approach, the very creation of the EU was explicitly justified with the goal of depoliticizing the then difficult issues of trade in coal and steal, in my view the explanation is more complicated.

Maria Weimer makes an important distinction between two types of legitimacy scientific and political. According to her "regulatory decisions taken under

\footnotetext{
${ }^{5}$ Les Levidow and Susan Carr, GM Food on Trial (Routledge 2010), p. 139.

${ }^{6}$ Ibid., p. 144.

${ }^{7}$ Communication from the Commission - The operating framework for the European Regulatory Agencies, COM (2002/0718 final),

${ }^{8}$ Levidow mentions that "some politicians" did sought that, and that comitology provided convenient way to do so. See Levidow and Carr, p. 151.
} 
conditions of scientific uncertainty [must be justified] along two different trajectories - scientific rationality, on the one hand, and the adoption of the final decision by a democratically accountable political institution which could remain detached from the scientific results on the other. " 9 There is a special emphasis on the "detached" here; if the political institutions merely rubber-stamp the received wisdom their decisions would be redundant and will be unable to confer the needed political legitimacy to the decisions. Naturally, for political institutions to take independent decisions they have to take into account some other reasons in addition to those considered by scientific advisors; if they were limited to the same considerations they will either have to second-guess their advisors or deviate from the received wisdom arbitrarily which are both implausible. ${ }^{10}$ As will be seen from the case study, the latter seems not to be the case with the established GMO regime. Weimer also observes that even if the framework in theory allows some "other" considerations to be taken into account (and respectively departures from received scientific advice to be justified) in practice the balance is shifted too much in favour of "sound science" so that everything that appears "extra-scientific" is discounted." As the following case study reveals, the science does crowd politics out of the decision-making, however it also crowds out the political legitimacy. The price of avoidance of the political conflict is, in Damian Chalmers words, the missed opportunity for successful mediation of all legitimate concerns of European citizens. ${ }^{12}$ The regime not only limits the range of possible concerns only to "science," but to a particularly narrow understanding of what "science" is.

\section{The New Regime}

Today the authorisations of GMOs are governed by two principle instruments: the Deliberate Release Directive ${ }^{13}$ and the Food and Feed Regulation. ${ }^{14}$ They are also

\footnotetext{
9 Maria Weimer, 'Legitimacy through Precaution in European Regulation of GMOs? From the Standpoint of Governance as Analytical Perspective ' in Christian Joerges and Poul F. Kjaer (eds), Transnational Standards of Social Protection Contrasting European and International Governance, vol 5 (ARENA Report No 5/08, RECON Report No 4 2008), p. 161. She postulates these two imperatives to apply to decisions pursuant to the precautionary principle, but in my view in the complex and rationalised democracies of today the same is valid for any authoritative decision.

${ }^{10}$ At the very least political institutions must be able to assign different weight to the same reasons that were considered by the scientific advisor. For a detailed argument how groups can reach nonarbitrary decisions of their own see Christian List and Philip Pettit, Group Agency. The Possibility, Design and Status of Group Agents (Oxford University Press 2011).

11 Weimer, p. 162.

12 See Damian Chalmers, 'Risk, Anxiety and the European mediation of the Politics of Life' 30 European Law Review 649.

${ }_{13}$ Directive 2001/18/EC on the deliberate release into the environment of genetically modified organisms (12 March 2001), hereinafter 'Deliberate Release Directive'.

${ }^{14}$ Regulation 1829/2003/EC on genetically modified food and feed (22 September 2003), hereinafter 'Food and Feed Regulation'.
} 
ruled by the General Food Law Regulation, ${ }^{15}$ which stipulates the general principles and the competent authority - the European Food Safety Authority (EFSA).

The principle of science-based regulation is enshrined in Art. 6 of the General Food Law Regulation: in order to achieve a high level of protection of human health food law should be based on risk analysis. In particular "risk assessment shall be based on the available scientific evidence and undertaken in an independent, objective and transparent manner" while "risk management shall take into account the results of risk assessment, and in particular, the opinions of [EFSA], other factors legitimate to the matter under consideration and the precautionary principle".

The substantive criteria for authorisation are the absence of "risks to human health and the environment, whether direct or indirect, immediate or delayed, which the deliberate release or the placing on the market of GMOs may pose."16 These risks may have different expressions in different cases, for example possible development of antibiotic resistance in animals or humans or of insecticide resistance in plants. The application of these criteria should be conditioned by the precautionary principle $^{17}$ and by consideration of the cumulative effects ${ }^{18}$ (with regard to earlier authorisations) and the scale of the projected release ${ }^{19}$. The Food and Feed Regulation requires further that the product should not be nutritionally disadvantageous to consumers, and should not have adverse effects on human and animal health or the environment. ${ }^{20}$ These are narrow and in practice exclusive grounds on which the authorisations are to be decided; the Deliberate Release Directive and the Food and Feed Regulation leave out quite a number of other considerations, which are relevant to Member States and stakeholders, like adverse effects on conventional and organic farming, coexistence and contamination, market need and available alternatives, industrial policy, ethics, respect for nature, sustainable development, economic and technological dominance, impact on third countries, consumer choice, regional development, protection of local traditions, etc. ${ }^{21}$ To sum up, the regulatory regime, and as we shall see the established practice of the Commission is aptly described by Maria Lee as "science must be fought with more science." 22

\footnotetext{
15 Regulation 178/2002 laying down the general principles and requirements of food law, establishing the European Food Safety Authority and laying down procedures in matters of food safety (28 January 2002),

${ }^{16}$ Article 2, para 8 of the Deliberate Release Directive.

${ }_{17}$ There is explicit reference to it in recital 8 of the Directive.

18 Id., recital 19.

${ }^{19}$ Id., recital 24.

${ }^{20}$ Food and Feed Regulation, art. 4, para 1.

${ }^{21}$ See Jane Holder, Maria Lee and Sue Elworthy, Environmental protection, law and policy : text and materials (2nd edn, Cambridge University Press 2007) for a comprehensive account of the considerations that are important for different stakeholders.

${ }^{22}$ Id., p. 86.
} 
Authorisation procedures vary according to the projected use of the GMO - whether it is intended for cultivation and whether it is intended for food and feed, ${ }^{23}$ but the common pattern, in a nutshell, ${ }^{24}$ is the following. The licensing process starts with an application through a national authority, which forwards it (together with its own opinion) to the specialised scientific body - EFSA, whose assessment of food and environmental safety is crucial in all cases of controversy, which means all cases. EFSA distributes the dossier to the other Member States which may make their own evaluations and submit their opinions to EFSA. The public is also invited to submit opinions, ${ }^{25}$ but it is unclear how can they be taken into account by EFSA if they do not qualify as objective and independent science. Levidow notes the irony: "prospective participants faced a dilemma: their wider comments would be predictably ignored, while technical comments would depend on specialist expertise in risk issues. Thus participation could not be equated with more democracy."26 Nevertheless, the opportunity to participate remains important as this is how groups like Greenpeace and Friends of the Earth get involved.

EFSA, as most other EU agencies, is not a regulatory authority with powers of its own but is only an independent source of advice. ${ }^{27}$ It is the institutional device supposed to confer scientific legitimacy to authorisations. If its opinion is positive, the Commission prepares a draft authorisation decision, which is submitted to the Standing Committee on Food Chain and Animal Health ("Food Chain Committee") - a regulatory comitology committee. So far the Food Chain Committee has never succeeded in forming a qualified majority neither for nor against any GMO authorisation proposal (thus exhibiting unprecedented failure of cooperation in comitology process $)^{28}$ and therefore the issue is referred to the Council. In turn, the

\footnotetext{
${ }^{23}$ In theory the Deliberative Release Directive creates regime of mutual recognition, and only in case of disagreement the decision is centralised by comitology and upon an optional advice of EFSA. However, Member States always rise and maintain objections, and the Commission always asks the EFSA opinion.

${ }^{24}$ For a more detailed account see Maria Lee, EU regulation of GMOs : law and decision making for a new technology (Edward Elgar 2008); for a more recent review see Mark A. Pollack and Gregory Shaffer, 'Biotechnology Policy. Between National Fears and Global Disciplines ' in Helen Wallace, Mark A. Pollack and Alasdair R. Young (eds), Policy-making in the European Union (6th edn, Oxford University Press 2010).

${ }^{25}$ Deliberate Release Directive, recital 46 and Article 9.

${ }^{26}$ Levidow and Carr, p. 153 with reference to Maria Paola Ferretti.

${ }^{27}$ For more details on EFSA see, Regulation 178/2002 laying down the general principles and requirements of food law, establishing the European Food Safety Authority and laying down procedures in matters of food safety hereinafter General Food Law Regulation.

${ }^{28}$ Pollack and Shaffer quoted a Commission report according to which "out of 2637 draft decisions submitted to the various EU expert committees that year, only eleven of those decisions (less than 0,5 per cent) were referred to the Council for a decision - and six of these involved authorisation of GM foods and crops." Pollack and Shaffer, 'Biotechnology Policy. Between National Fears and Global Disciplines'
} 
Council so far has never reached qualified majority to block the decision ${ }^{29}$ and in such cases the matter is referred back to the Commission for final decision. ${ }^{30}$ This decision as a matter of course is positive and is justified with the respective positive EFSA opinions, although sometimes the Commission remands it to EFSA for further information. When the GMO is finally authorised it enjoys the freedom of movement on the territory of any Member State. It can be restricted by Member States only "on the basis of new or additional scientific knowledge, [that the licensed GMO] constitutes a risk to human health or the environment." 31 Presently there are only two GMO authorised for cultivation, about a dozen for food and feed and some eight Member States have invoked safeguard clauses. ${ }^{32}$

Thus, the GM authorisation procedure is centralised, although Member States have opportunities to engage actively both in the assessment process by submitting their own evaluations and in the management through their representation in the comitology committee and in the Council. Formally EFSA is in no way superior to national (or any other expert authorities); they are all peers as players in the scientific field should be. Yet, its superior information and expertise could make EFSA what Levidow calls "cognitive authority" which can accommodate or challenge national expertise..$^{33}$ Similarly Damian Chalmers described it as "normative authority" which could affect individual and institutional choices on food safety within the European Union. ${ }^{34}$

The regime places special value on gathering all expertise so that the regulatory decisions are informed by all relevant data available. ${ }^{35}$ This is to be achieved by "networking of risk assessors through agency structures [which invite] national perspectives on risk into the EU system" 36 with EFSA in the centre. This is sophisticated, even Bayesian regime, which is apparently reliant on the assumption that differences of opinions between EFSA and the national expert authorities are due to differences in the available information and therefore if all relevant information is made common knowledge the opinions will converge:

\footnotetext{
${ }^{29}$ The exception being its decisions from 24 June 2005, 18 December 2006 and 20 February 2007 to block infringement proceedings against Member States for bans of authorised GMO's.

${ }^{30}$ Now the comitology procedure is thoroughly reviewed with regard to the Lisbon Treaty. Maria Weimer provides an in-depth account of the consequences for the GMO regulation in the op.cit. In my view whatever the changes, their effect will have negligible significance on this issue as the root of the problem is not in the procedure.

${ }^{31}$ This is the 'safeguard clause', see Art. 23 of the Deliberate Release Directive.

32 The data is provided from Marianna Schauzu, 'The European Union's Regulatory Framework' in Michael Baram and Mathilde Bourrier (eds), Governing Risk in GM Agriculture (2011).

${ }^{33}$ Levidow and Carr, p. 140.

${ }^{34}$ Damian Chalmers, 'Food for Thought': Reconciling European Risks and Traditional Ways of Life' 66 Modern Law Review 532, p. 540.

${ }^{35}$ There is a special regulation on this, see Commission Regulation 2230/2004 laying down detailed rules for the implementation of Regulation No 178/2002 with regard to the network of organisations operating in the fields within the EFSA's mission (23 December 2004).

${ }^{36}$ Lee, p. 68.
} 
Where the Authority identifies a potential source of divergence, it shall contact the body in question to ensure that all relevant scientific information is shared and in order to identify potentially contentious scientific issues. ${ }^{37}$

If they nevertheless fail to reach common conclusions, EFSA is required to state the remaining differences in its final opinion:

the Authority and the national body shall be obliged to cooperate with a view to either resolving the divergence or preparing a joint document clarifying the contentious scientific issues and identifying the relevant uncertainties in the data. This document shall be made public." 38

One may wish to think that laying out the divergent opinions in a public document EFSA is supposed to abstain from conclusion and leave to the political institutions to draw the final conclusion but this is not the case. EFSA does summarise the contrary evidence but still makes its own conclusions. The Commission either accepts its conclusions or questions again, but never takes a view of its own. Nevertheless, the arguments and counterarguments are in the public domain and allow to the resourceful public to challenge them. Own conclusions could be legitimately drawn in theory on the basis of the available counterarguments by the Food Chain Committee; there sit experts from Member States who can engage in a meaningful debate. However at that stage the national positions have already ossified and the experts can only stick to their guns.

The cognitive authority of EFSA however is undermined in two ways. First, the expertise in the field of food and environmental safety is very much contextdependent; as will be seen what is indisputably safe in the Netherlands may be hazardous in Italy. In theory, the networking should solve this problem and maintain the cognitive superiority of EFSA, as it is supposed to be adequately informed by the Italian experts, while they are likely to remain unaware that the risk they fear is nonexistent elsewhere. ${ }^{39}$ The other problem is that EFSA is too reliant on the information fed by the applicants; it does not make independent safety tests itself but can only examine the received data. With several case studies of authorisations of GM maize van Asselt and Vos concluded that "EFSA's risk assessments are de facto metareviews of [applicant's] assessment instead of independent examination." 40 What

\footnotetext{
${ }^{37}$ General Food Law Regulation, art. 30 (2).

${ }^{38}$ General Food Law Regulation, art. 30 (2), emphasis added. An recent example of such resolving of differences was a study on long term effects of GM maize on rats, commissioned and presented in the Food Chain Committee by Austria. See the minutes from the proceedings of EFSA GMO panel on 3-4 December and of the Food Chain Committee on 16 December 2008 and 19 October 2009 respectively. Later Austria withdraw the study.

${ }^{39}$ As will be seen latter, in practice the problem often remains as the local safety issues arise only in relation to "extra-scientific" issues like the health or farming policies, consumption patterns, etc which are not taken into account by EFSA.

${ }^{40}$ Marjolein B.A. van Asselt and Ellen Vos, 'Wrestling with uncertain risks: EU regulation of GMOs and the uncertainty paradox' (2008) 11 Journal of Risk Research 281, p. 284. More alarmingly they noticed examples that EFSA failed to be even such quality check: the applicant did not disclose an
} 
EFSA does is peer review; it is the legitimate mode of seeking the truth in the scientific field indeed hence its wide-spread use in science-based regulation. Yet it is apparent that in the field of regulation the applicant is not an independent expert seeking only the truth but also working for profit. ${ }^{41}$ Even in ideal circumstances this gives the applicant opportunity to frame the safety issues in the most favourable light and stack the deck in such a way to amount to what may be called informational capture. ${ }^{42}$ To mitigate the problem in 2006 the Commission was instructed to specify which specific protocols the applicants shall use in their safety study. Member States can and some of them do commission studies of their own, yet apparently if EFSA is not to make independent tests of its own, the regime remains geared to favour the applicant. For these reasons the expected cognitive authority of EFSA is not unquestionable; as Levidow aptly noted for its decade of existence EFSA became from an arbiter the defendant. ${ }^{43}$ In my view this is also because of the inappropriate burden that was placed on it as agent of Science and this will be illustrated once again in the Amflora case study below.

\section{The Amflora saga ${ }^{44}$}

Amflora is a starch potato, genetically modified for higher content of amylopectin, which is used mostly in the paper industry. It is not intended for human and animal consumption, but some by-products (i.e. pulp) can be used for feed, and inadvertent and technically unavoidable amounts in food cannot be excluded. The application for its cultivation was initially filed in 1996, and in 2003 it was resubmitted as per the new Deliberate Release Directive through the Swedish national authorities (where it was intended to be grown). In 2005 the applicant (BASF) filed also an application under the Food and Feed Regulation, through the British authorities with regard to the inadvertent food and feed use. The assessment of the Swedish authority found Amflora to be safe, in a language worth quoting: "the result of the risk assessment does not call for risk management actions. The potential risks are very small and connected with certain unlikely changes of the potato and effects that have not been

unfavourable study that was available to him and even when this became publicly known EFSA took no action.

${ }^{41}$ I haste to distinguish myself from the popular corporations-bashing crowd; companies do care for safety and for their image; on the other hand experts have their own dependencies and biases as well. Nevertheless, companies' concern for safety is conditioned by the precise boundaries of their legal liability and by their PR policy so they balance the safety and profit concerns quite differently.

42 Accusations that EFSA is captured by the biotech industry come from environmentalists and even from academia; in my view whether this is the case is contingent because the very design of the regime creates the problem.

${ }^{43}$ Levidow and Carr, p. 153.

44 The case study is based only on the documents which are published. The opinions of the national authorities which were discussed by EFSA and the Food Chain Committee are known only to the extend that they are addressed in the minutes from the proceedings of the relevant European institutions. The opinions of the NGOs are taken from publications on their own web sites. 
anticipated in the risk assessment." 45 This is exemplifying how the functional separation between risk assessment and risk management renders the latter redundant. For the unanticipated effects would suffice the proposed monitoring plan which "constitutes a system fit to detect the potential occurrence of unanticipated events that might lead to adverse effects on human health, animal health and the environment." 46

The Commission distributed the application to the other Member States and asked EFSA to opine "whether there is any scientific reason to believe that placing on the market of the genetically modified potato ... is likely to cause any adverse effect on human health or the environment." 47 Some of the Member States also delivered opinions, raising various concerns which EFSA took care to address. In particular, Member States had various objections to the Amflora in terms of its molecular characterisation, allergenicity, toxicity and inadequacies of the monitoring plan and of the detection method. EFSA addressed the concerns issue by issue.

In December 2005, EFSA answered all of the concerns unequivocally and delivered its conclusion that "the information available for the potato [Amflora] addresses the outstanding questions raised by the Member States and considers that [it] is unlikely to have an adverse effect on human health or the environment in the context of its proposed uses." ${ }^{48}$ From these, only the possible spread of antibiotic resistant genes from Amflora into the environment became a point of major controversy.

The Amflora Opinion 2005 contains several caveats about the limits of the current state of knowledge, which is not surprising given that the effects of an invention are being assessed i.e. we are on the borderlines of our knowledge and all probabilities are uncertain. As Maria Lee notes, "everything that we know about the GMOs lies in the shadow of ignorance, the prospect of harm that we have not even thought of." 49 Indeed, several "unexpected" traits and effects have been observed by the studies, yet EFSA concluded that none of them were unusual in the area. For example some Member States were concerned by a study of rats fed on Amflora, some of which exhibited increased number of cysts. To this EFSA responded that: "Thyroid cysts occur commonly in rats, while their frequency varies during ageing [therefore their] slightly increased incidence ... in male [rats] fed on transgenic potato is likely to be

\footnotetext{
${ }_{45}$ Assessment report of the Swedish Competent Authority on the placing on the market according to notification C/SE/96/3501.

${ }^{46} \mathrm{Ibid}$.

${ }^{47}$ EFSA, Opinion of the Scientific Panel on GMO on a request from the Commission related to the notification (Reference C/SE/96/3501) for the placing on the market of GM potato EH92-527-1 with altered starch composition, for cultivation and production of starch, under Part C of Directive 2001/18/EC from BASF Plant Science (2006), published in The EFSA Journal (2006) 323, 1-20, hereinafter Amflora Opinion 2005. Actually there were two opinions, with almost identical content - for the purposes of the Deliberate Release Directive and of the Food and Feed Regulation respectively. All references below will be to the opinion pursuant to the Deliberate Release Directive.

${ }^{48}$ Amflora Opinion 2005.

${ }^{49}$ Lee, p. 29.
} 
due to natural variability and does not trigger a further assessment."50 EFSA seemingly did its best to account for ignorance and to assess every effect imaginable in our present state of knowledge, with the most outstanding example being: "the hypothetical ORF4 protein showed a high degree of similarity with two proteins that are not known to be toxic or allergenic." ${ }^{51}$ Another example is EFSA's opinion on allergenicity: its panel concluded that there is no evidence for any, but noted that " $\mathrm{A}$ weight of evidence approach is recommended, taking into account all of the information obtained with various test methods, since no single experimental method yields definitive evidence for allergenicity." 52 All of these statements were worth quoting to bring home the point that the scientific assessment is a matter of judgement and is by no means hard and fast conclusion as we laymen are used to think of it.

It is striking that despite its acknowledgment of the limits of knowledge on some issues, EFSA never even mentioned the precautionary principle. More often than not it took the lack of evidence for adverse effects to mean certainty of their absence. For an expert body this is understandable: in science the Razor of Occam ${ }^{53}$ requires one to be parsimonious when drawing conclusions from scant evidence. A scientist should presume non-existence of certain causal effect or untoward consequences. On the other hand risk management is to be governed by precaution, not by parsimony. Thus the functional separation between risk assessment and risk management, embodied by EFSA-Food Chain Committee/Council, appears to be particularly inept. When the parsimonious expert concludes in his assessments that risk is unlikely, precaution cannot be triggered and the risk manager cannot intervene at all; there simply is nothing to be managed. This is precisely what the Swedish national authority concluded. This is why Maria Lee generalises that "our regulatory systems ... generally discount ignorance" ${ }^{\prime 54}$ and this is how in cases of apparent uncertainty precautionary principle remains redundant.

Maria Weimer makes the same point in more practical terms:

in the phase of risk assessment, no open deliberation about the value judgements and framing assumptions - which are an inherent part of scientific reasoning under conditions of 'scientific uncertainty' - takes place. Secondly, the understanding of the opinions of the EFSA as objective and neutral scientific facts creates a strong

\footnotetext{
50 Amflora Opinion 2005, p. 10. Emphasis added, note how little the language of this scientific assessment differs from that of a moral judgement.

${ }^{51}$ Amflora Opinion 2005, p. 11

52 Amflora Opinion 2005, p. 11, emphasis added.

${ }^{53}$ This is the popular name of the methodological principle, initially formulated by Duns Scotus in 13c $\mathrm{AD}$ also known as the Law of Parsimony, "which prohibits, without a proven necessity, the multiplication of entities, powers, principles or causes" William Hamilton, Discussions on philosophy and literature, education, and university reform (Harper \& Brothers 1856), p. 580. It is still dominating scientific reasoning today: "nature may or may not favour simplicity, but we should certainly do so simply as a matter of rational procedure. ... [this is] a methodological tool of inquiry." Nicholas Rescher, Aesthetic factors in natural science (University Press of America 1990), pp. 3-4.

${ }^{54}$ Lee, p. 29.
} 
attraction for the risk managers to prioritise scientific arguments over those of an "extra-scientific", political nature. 55

The problem with the regulation of uncertainty is not that science is not sufficiently hard and fast; the problem is that people, experts and policy-makers alike, often treat it as hard which means that the other relevant considerations are relatively "softened."

Some national authorities disputed EFSA's estimations on the scientific premises and presented studies with different results. On 9 March 2006 the Council criticised EFSA and asked "safety assessment [to] take greater account of the possible long-term consequences of the use of those products" and also recommended that scientific research should be intensified in this context. ${ }^{56}$ The Council also emphasised on "the need for coordination between all the bodies concerned, particularly the Commission, the European Food Safety Authority and the competent national authorities" in line with the assumption that this will settle the differences. ${ }^{57}$

Thus the debate for the role of EFSA and scientific expertise was reopened. In April 2006 the Commission announced seven measures intended to improve scientific consistency and transparency of risk assessments and also to develop consensus between all interested parties. ${ }^{58}$ EFSA was instructed to liaise and communicate with national scientific bodies with a view to resolve possible diverging scientific opinions, to take account of the reasoned objections from Member States and to justify any deviations from them. ${ }^{59}$ The Commission also announced that when such objections are not properly addressed, it will suspend the proceedings and refer back the question for further considerations. ${ }^{60}$ According to Levidow and Carr this was a signal that the Commission would not accept any more EFSA to be the ultimate arbiter judging (against) national objections. ${ }^{61}$ In my view, even if the Commission ever had such intentions, they never materialised and since 2006 it continued to eventually defer to EFSA's opinions on GMO authorisations as it did before. And even if the announced measures were intended to signal that the Commission would require consensus to be developed or would adopt opinions of its own, it is doubtful whether this would be possible in the first place because the Pfizer doctrine of the

\footnotetext{
${ }_{55}$ Weimer, p. 195.

${ }_{56}$ Press release from the $2713^{\text {th }}$ Council Meeting (Environment), 9 March 2006, 6762/06 (Presse 58), http://www.consilium.europa.eu/uedocs/NewsWord/en/envir/88721.doc (accessed 10 April 2010).

${ }^{57} \mathrm{Ibid}$.

${ }^{58}$ See Commission press release from 12 April 2006 (IP/06/498) available at

http://europa.eu/rapid/pressReleasesAction.do?reference=IP/06/498, last accessed on 30 July 2011.

59 Ibid.

${ }^{60}$ Indeed it remanded the Amflora dossier back to EFSA several times.

${ }^{61}$ Levidow and Carr, p. 155. However he emphasises that there is an important trade-off: "As a practical reform, [new measures] could provide a way to accommodate more Member States through greater rigour and thus potentially gain more votes for Commission proposals. On the other hand, if greater transparency meant a more explicit uncertainty, then this could undermine safety claims as 'objective' advice." (Ibid).
} 
General Court would require it to base such decision on alternative scientific grounds of quality equal to that of EFSA. ${ }^{62}$

Thereafter, EFSA hosted several technical meetings with national experts on which the issues related to Amflora and two GM maize varieties were discussed. ${ }^{63}$ In November EFSA adopted an annex which listed all objections from the Member States and how its opinion integrated each of them. ${ }^{64}$ According to Commissioner Dimas "All Member States ... confirmed that, based on information available at the current time, the corresponding EFSA opinion satisfactorily addressed their scientific objections." 65

Despite Dimas' claim some Member States remained unconvinced at least with regard to one issue: antibiotic resistance. Amflora contains nptII - an antibiotic resistance marker gene (ARMG). ARMGs are introduced during the process of genetic modification to distinguish the cells which were successfully modified from the rest. ${ }^{66}$ The nptII confers resistance to kanamycin, neomycin and several other antibiotics, which according to EFSA were of "limited use in human and veterinary medicine." 67 This statement was based on an earlier general opinion on antibiotic resistance, where EFSA classified the ARMG in three groups, putting the nptII in group I - ARMG which are safe to use because (1) these genes are already widespread in nature anyway and (2) because they confer resistance to antibiotics which "have no or only minor therapeutic relevance in human medicine and only restricted use in defined areas of veterinary medicine." ${ }^{68}$ Quite unfortunately for our potato, in 2005 the World Health Organisation (WHO) issued a report, in which it classified kanamycin and neomycin as "critically important antibacterials." 69 Greenpeace brought the issue to the attention of the Commission, and the Commission mandated the European Medicines Agency (EMA) to opine on the

\footnotetext{
${ }^{62}$ Ironically the very same efforts to make EFSA the best cognitive authority by integration of expertise from national authorities and develop consensus between them undermine the capacity of the Commission to find alternative scientific grounds to justify such decisions.

${ }^{63}$ Meetings held on 15 May 2006 and 19 June 2006.

${ }^{64}$ Ibid.

${ }^{65}$ Commissioner Dimas answering a written question by Alyn Smith, MEP (E-0769/2007)

http://www.europarl.europa.eu/sides/getAllAnswers.do?reference=E-2007-0769\&language=EN

(accessed 9 April 2010).

${ }_{66}$ The antibiotic resistance had been a contentious issue in EU for quite some time and beyond the GMO debate; this was the bone of contention in the landmark Pfizer case as well. There was a proposal in the European Parliament for immediate ban of ARMG in GMOs which was defeated; however it was enshrined into law that ARMGs should be phased out by 2005.

${ }^{67}$ EFSA Opinion 2004, p. 13.

${ }^{68}$ EFSA, Opinion of the Scientific Panel on GMO on the use of antibiotic resistance genes as marker genes in genetically modified plants (2004), Hereinafter "ARMG Opinion", p. 11.

${ }^{69}$ World Health Organisation, World Health Organisation, Critically Important Antibacterial Agents for Human Medicine for Risk Management Strategies of Non-Human Use. Report of a WHO working group consultation (2005)
} 
importance of these drugs. ${ }^{70}$ In 2007 EMA concluded that kanamycin and neomycin are valuable antibiotics and "cannot be classified as of no or minor importance."71 Asked again by the Commission, EFSA in a Statement from 2008, agreed that kanamycin and neomycin are important, yet repeated its original conclusion that nptII is safe to use, because its horizontal transfer (from plants to bacteria) was very unlikely, and it was widespread in nature anyway.72 Following that, the Commission proposed to authorise the Amflora for food and feed use through comitology. The Food Chain Committee failed to reach a qualified majority on 10 October 2007 and the decision was referred to the Council, which also failed to obtain majority on 18 February 2008. Under the rules of comitlogy, Council's failure to take position brings the issue back to the Commission which adopts the proposal. ${ }^{73}$ Latter that year BASF started a lawsuit before the General Court against the Commission for failure to act.

In the meantime Greenpeace submitted a legal brief written by a London QC, arguing that the adoption of authorisation decision would be unlawful. The argument was developed on the basis of the changed classification of the antibiotics: if kanamycin and neomycin can no longer be considered as antibiotics of minor importance, the gene which transfers resistance to them cannot be classified in group I (safe to use) of the ARMG Opinion, but in the unsafe group II (to be used only in field trials) or even in group III (to be avoided, "irrespective of considerations about the realistic value of the treat"). More importantly, the Deliberate Release Directive requires "identifying and phasing out of antibiotic resistance markers in GMOs which may have adverse effects on human health and the environment." ${ }^{\prime 4}$ Thus, from the EFSA's own ARMG Opinion follows that ARMG conferring resistance to important antibiotics are to be considered as not safe for human health, and as nptII confers resistance to so classified antibiotics, it should be considered as having adverse effect under the Directive, therefore it should be phased out.

Although Council's inaction had cleared the way for Commission to authorise the Amflora alone, in May 2008 it asked EFSA yet again for a consolidated opinion on the safety of Amflora and EFSA repeated its conclusions once again. This time there

\footnotetext{
${ }^{70}$ In the meantime the Commission proceeded with the authorisation pursuant to the Deliberative Release Directive, proposing approval through the comitology, which on 19 December 2006 failed to reach decision and the matter was referred to the Council, which also failed on 16 July 2007. This cleared the way for Commission approval of deliberative release and marketing, but it withheld it until the controversy pursuant to Food and Feed Regulation continued.

${ }^{71}$ EMEA, 'Committee for Medicinal Products for Veterinary Use And Committee For Medicinal Products For Human Use Presence of the ARMG nptII in GM plants for Food and Feed Uses' EMEA/CVMP/56937/2007 ibid., hereinafter 'EMEA Opinion', at p. 2. It also indicated few other misgivings in the EFSA opinion, esp. noting that the occurrence of kanamycin resistance, which was judged as widespread by EFSA actually varies substantially between countries and species.

72 EFSA, Statement of the Scientific Panel on GMO on the safe use of the nptII antibiotic resistance marker gene in genetically modified plants (2007),

${ }^{73}$ The procedure is governed by Council Decision of 28 June 1999 laying down the procedures for the exercise of implementing powers conferred on the Commission.

${ }^{74}$ Deliberate Release Directive, Art. 2, para 2.
} 
were two (out of twenty) panel members dissenting. One of the dissents emphasised that only "the current state of the knowledge" indicates that the antibiotic resistance genes are safe, and if this turns out to be otherwise, the consequences on health and environment are unknown. The other noted that even though the probability of horizontal gene transfer is low, "given the magnitude and multitude of exposures from the foreseen use of GM plants with [ARMG] it appears the cumulative probability of transfer could range from unlikely to high."75 With this final reassurance, the new Barroso Commission, in one of the first acts after its formal inauguration, adopted two decisions (pursuant the Deliberative Release Directive and the Food and Feed Regulation) which authorised Amflora to be cultivated, marketed, and used as food and feed throughout the Union.

The Commission was very careful when deciding this sensitive and salient issue (indeed, it abstained from deciding when it could) but kept within the range of relevant premises established conservatively by EFSA. It took note of the divergent opinions, but all it did was to ask EFSA to reconsider and possibly change its position, rather than forming own position different from the received wisdom. Eventually it deferred to EFSA's conclusion, which was probably anticipated by the other participants, so the struggle was to undermine the premises on which EFSA's conclusion was based. Notably, the Commission consciously avoided to venture in arguments on broader grounds, such as placing the Amflora safety in the context of the national health policies, the existing farming practices or questioning the reliability or sufficiency of the expertise itself. There was no discussion on whether the precautionary principle can or should be applied. Both the Commission and EFSA failed to consider the probability of horizontal gene transfer in the context of the projected large scale release. As one of dissenting members of EFSA's panel noticed, even very low probabilities may become concerning when the number of incidents grows. This is how socio-economic considerations (projected scale of cultivation) have direct bearing on the scientific assessment (likelihood of horizontal transfer). Similarly, low probabilities are of little assurance when the long-term effects of such events are considered (as EFSA was instructed to do): even few horizontal gene transfers may be sufficient for development of antibiotic resistant founder generation of bacteria; on the other hand there is increasingly high level of antibiotics found in soil and plants (here the context of other Community and national policies - on antibiotic use should be taken into consideration) which provides them with positive selection pressure to flourish. Perhaps in order to avoid such debates, the Commission decided to authorise the cultivation and use of the Amflora under a written procedure on 2 March 2010. Broader considerations may or may not have been discussed in the College meeting held on the next day, 3 March 2010, when it decided to introduce "quickly" changes of the GMO regime "which [should] guarantee that any decision adopted was based entirely on independent

\footnotetext{
${ }^{75}$ EFSA, 'Statement of EFSA on the consolidated presentation of opinions on the use of antibiotic resistance genes as marker genes in genetically modified plants' The EFSA Journal 1108 Appendix D.
} 
scientific advice, in particular that of the European Food Safety Authority, and at the same time respected the choices made by Member States on whether or not to authorise GMO crops on their territory."76 As reason for this the commissioners mentioned mainly the principle of subsidiarity, thus implicitly acknowledging that the country specific concerns could not be adequately taken into consideration in the pan-European regime. The first authorisation for cultivation brought home what was a public secret from the very beginning - that the GMO-averse Member States had considerations other than safety narrowly defined, which were banished out by the existing regulation.

\section{Epilogue}

The regime change did not come out of the blue. From the very establishment of the current regime some Member States started to issue bans against the newly authorised GMOs. Weimer for one had noted that this could be seen as herald for another crisis. ${ }^{77}$ In order to respond to the obvious functionality problems of the current GMO regulation in December 2008 the Council invited the Commission to make an evaluation of the legislation with a view for possible changes. ${ }^{78}$ Sara Poli notes that one could expect that the Commission would wait for the evaluation to be completed before introducing the amendments yet it was in a hurry and tabled them on 13 June 2010. Certainly, the regime collapse was not caused by the authorisation of the Amflora, yet my guess is that it was hastened by it. Another reason to think so is that in May 2010 an impact assessment leaked to the press disclosed that the Commission intended that the national opt-outs will speed up the GMO authorisations at EU level and have "a positive impact on biotechnology and seed companies compared to the status quo."79 For this reason many of the GMO opponents were initially hostile towards the proposed regime change. Another reason for the Commission to haste may be the citizen's initiative for prohibition of GMOs in EU. It is conspicuously absent from the discussions of the amendment yet it is fair assumption that the Commission would wish to relieve the pressure from one million citizens calling for such a ban by allowing the states to satisfy such wishes of their populations.

The proposed regime change itself is perhaps not so fundamental; indeed most of the legislation shall remain intact and the authorisations both for cultivation and use of

\footnotetext{
${ }^{76}$ Minutes of the 1907th meeting of the Commission held in Brussels (Berlaymont) on Wednesday 3 March 2010 (PV(2010)1907 final), at p. 23 available at http://ec.europa.eu/transparency/regdoc/ rep/10061/2010/EN/10061-2010-1907-EN-F-0.Pdf, (Accessed on 2 April 2012).

${ }_{77}$ Weimer, 'Legitimacy through Precaution in European Regulation of GMOs? From the Standpoint of Governance as Analytical Perspective', p. 162.

${ }^{78}$ For details see Sara Poli, 'The Commission's New Approach to the Cultivation of Genetically Modified Organisms' (2010) 1 European Journal of Risk Regulation 339.

${ }^{79}$ See Euractiv, Paper reveals EU plan to boost GM crop cultivation, published on 4 May 2010, available at http://www.euractiv.com/cap/paper-reveals-eu-plan-boost-gm-crop-cultivation-news-493647, last accessed 2 April 2012.
} 
GMOs will remain centralised. The amendment only provides opportunity of Member States to ban cultivation of authorised GMOs while their free movement for food and feed remains unaffected. ${ }^{80}$ Yet, the amendment is a sign of collapse of the whole GMO regime because it came with almost explicit admission that the European level authorisations are tortuous, the competent EU authorities are distrusted and the decisions fail to take into account the concerns of Member States. There are not many other examples when the EU shifts conferred competences back to the states and does so on its own initiative. It is also remarkable that on this issue comitology failed all the times; the only cases when the Council could decide on anything were when it prevented the Commission from prosecuting Member States for violation of the GM regime, thus in effect suspending it.

The Commission seems undisturbed by any of the above however. In the end of 2011 the long awaited evaluation of the GMO regime in EU by two independent consultancies was published and it was positive. The Commission claimed that the authorisation regime is "on the right track." 81 It admitted problems only in the application of the regime the solution to which would be provided by the national bans. Yet the national bans may be unworkable in the contexts of the common market and of the WTO regime (which is also one of science based regulation). An opinion of the Council's legal service leaked to the press in the autumn of 2010 raised concerns that they may be illegal both under the EU primary law and the WTO agreements. In July 2011 the European Parliament approved the amendments on first reading, but the draft stalled in the Council.

In December 2011 EFSA, which gathered the lion's share of the bashing for proindustry bias had to adopt new independence policy. Now it opens its scientific meetings to observers "in a pilot project." Welcome as it is, this move will hardly make much difference. The problem with its alleged informational capture is not (only) a matter of institutional design. Taking into account "all the scientific information available" as it should, EFSA cannot help the fact that the information on new technologies originates predominantly from the industry. This is not a problem which can be resolved under the current regime.

Notwithstanding this, there is plenty to be desired from the agency itself. Now five Member States - Hungary, 82 Austria, Luxemburg, France and Poland have challenged the authorisation of Amflora. As another blow to EFSA, the claimants ask for annulment of the decisions for manifest error of assessment, raising the antibiotic resistance issue and referring to the reports of WHO and EMA discussed above. If the judicial review for manifest error is as rigorous as it was in Pfizer and the General

\footnotetext{
${ }^{80}$ The scope and the grounds of such bans are still debated and merit separate article.

81 'GMOs: EU's legislation on the right track, evaluation reports conclude,' European Commission press release, 28 October 2011, http://europa.eu/rapid/pressReleasesAction.do?reference=IP/11/1285, last accessed on 2 April 2012.

${ }^{82}$ Case T-240/10, Hungary v. European Commission, action brought on 27 May 2010.
} 
Court pays same attention to the quality of scientific evidence on which the Commission based its decision, it should rule for the claimants because of the contradiction of the Amflora Opinion 2005 with the ARMG Opinion, if nothing else. After so many calls for peer review of EFSA's assessments it is now for the General court to engage in such independent review of the scientific reasoning.

For its part BASF did not emerge as a winner of the authorisation regime either. Its 2010 crop in Sweden was contaminated with another GM variety, which is not yet authorised (thus demonstrating the difficulties of co-existence). In January 2012 BASF announced that it withdraws its GM production from Europe due to the lack of acceptance..$^{83}$

Whither science-based regulation? The story shows that the expectation that science can bring about smooth decision-making and resolve the controversies were in vain. Certainly EFSA failed to become a normative authority guiding choices. The regulatory regime as a whole also functioned unsatisfactorily but one can argue that the failures were due to contingencies and science has not failed in principle; it was perhaps just EFSA who used it inconsistently (with regard to the antibiotic resistance issue) and defined what counts as scientific argument too narrowly. Perhaps it was only one particular version of science that failed, partly because of the legislative framework and partly because of inept application. Finally, the story may have no bearing on scientific regulation at all, as everybody recognised that states have other reasons in mind, even if they were using scientific counterarguments as proxies. Given that the real concerns of Member States are excluded from the debate, the collapse of the regime should come as no surprise.

In my view the case study illustrates the unsustainability of the concept "fight science with science" which places unbearable burden on science. The overreliance on science frustrated the expectations, and undermined the legitimacy of the regime itself. It also undermined the legitimacy of science: "To put it dramatically, the result of the "sound science" approach is, therefore, not the depoliticisation of European GMO regulation, but, on the contrary, the disguised politicisation in favour of only one "extra-scientific" aspect of it: namely, the objective of the free trade of GM products." ${ }^{84}$ At the very least it exposed the flaws of the functional separation between risk assessment and risk management. Indeed, there is a growing awareness of this problem in the academia. From the side of lawyers, Alemanno maintains that risk assessment is not a fully objective exercise because it is influenced by "the values and beliefs of scientists and the judgements of the profession. In other words, when dealing with decisions involving technical and scientific aspects, scientific expertise and political decisions become so intertwined as to become

\footnotetext{
${ }^{83}$ This leaves the maze MON 810 (authorized in 1998 under the old regime) the only GM crop currently grown in Europe.

${ }^{84}$ Weimer, 'Legitimacy through Precaution in European Regulation of GMOs? From the Standpoint of Governance as Analytical Perspective', p. 195.
} 
impossible to separate." 85 From the side of the scientists Morris and Spillane hold the same: "science and policy making are two arenas that are not cognitively and culturally distinct but rather engaged in process of constant exchange and mutual stabilisation." 86 The present case study is just another confirmation how much this is so.

Finally, the collapse of the GMO authorisation regime raises one constitutional issue as well. A centralised regulatory procedure with no central regulatory authority which functions in a decentralised polity spanned by a homogenous internal market seems unlikely to become a paragon of successful institutional design. Alas, this is the tragedy of a polity which is and wants to remain decentralised; the current constitutional framework of the EU is here to stay, and we are bound to find a solution within it. ${ }^{87}$ Indeed, an easy solution to the regulatory problem would be the creation of a centralised regulator with decision-making rather than advisory function, comparable to the Food and Drug Administration in the United States. But it is likely to exacerbate the legitimacy problem, as presently no European agency seems sufficiently trusted by the citizens to be made responsible alone. As Chalmers observed, citizens are legitimately anxious about what they eat, ${ }^{88}$ and they have little reason to leave this issue to an obscure expert regulator based in an Italian town they can associate only with its football team. On the other side it is true that in order to gain trust, an agency must be made responsible to take certain decisions in the first place. In principle, EFSA could gain more trust and responsibilities step by step, yet for the decade of its existence it has made remarkably little progress and its handling of the Amflora case only worsened the situation. The functional separation between risk assessment and risk management was supposed to allow decentralised decisionmaking in a centralised authorisation process and it is regretful that it proved unworkable, because we have not yet invented another alternative to the centralisation. Whether this means that we are bound to move towards a model of centralised regulation and towards the next level of federalisation of the EU is a question beyond the scope of the current paper.

\footnotetext{
${ }^{85}$ Alberto Alemanno, 'EU Risk Regulation and Science: The Role of Experts in Decision-making and Judicial Review' in Ellen Vos (ed), European Risk Governance: Its Science, its Inclusiveness and its Effectiveness, vol 6 (CONNEX 2008) ibid., p. 47.

${ }_{86}$ Morris and Spillane, p. 368, with reference to Sheila Jasanoff.

${ }^{87} \mathrm{It}$ is common feature of the EU to achieve its goals by creation of baroque governance structures which in most other cases work surprisingly well. Comitology for example is a mechanism unseen in any other constitutional system which regularly squares such circles. For a seminal article see Christian Joerges and Jurgen Neyer, 'From Intergovernmental Bargaining to Deliberative Political Processes: The Constitutionalisation of Comitology' 3 European Law Journal 273

${ }^{88}$ See Chalmers, 'Risk, Anxiety and the European mediation of the Politics of Life'
} 